\title{
Cytogenetic Analysis of Primary Cultures and Cell Lines: Generalities, Applications and Protocols
}

\author{
Sandra Milena Rondón Lagos ${ }^{1}$ and Nelson Enrique Rangel Jiménez ${ }^{2}$ \\ ${ }^{1}$ Doctoral Program in Biomedical Sciences, Universidad Del Rosario \\ ${ }^{2}$ Azienda Ospedaliero-Universitaria S. Giovani Battista di Torino \\ ${ }^{1}$ Colombia \\ 2Italy
}

\section{Introduction}

Cytogenetics constitutes an important diagnostic tool to determine and/or confirm specific syndromes nowadays; its use is directed towards the selection of treatments and monitoring of patients using different procedures. These latter are carried out in order to obtain a karyotype from peripheral blood or several tissue biopsies (e.g. biopsies from patients with melanoma, breast cancer, skin biopsies, foreskin samples, abortion products, among others). However, the study of chromosomal abnormalities in culture cells has been limited by complex processes such as achieving cell growth and a good number of metaphases, which in turn hampers the chance to obtain a useful number of metaphase spreads in order to carry out a proper cytogenetic analysis, that should be able to display a good morphology, an adequate dispersion and a correct banding. Cell lines are widely used in different research fields, particularly in invitro models for cancer research. (Burdall et al., 2003)

Given the importance of the model used to examine and manipulate potentially relevant molecular and cellular processes underlying malignant diseases, it is necessary to achieve an accurate and comprehensive karyotyping for cultures of different cell lines. In turn, karyotyping provides an insight into the molecular mechanisms leading to cellular transformation and could allow clarifying possible cytogenetic aberrations associated to drugs exposure and the development and progression of different types of cancer. The fast increase observed in cancer incidence is forcing us to carry out more identification studies of cytogenetic biomarkers associated to development of this disease, which could contribute for a better understanding of the carcinogenic process and could also have enormous implications for the development of effective anticancer therapies.

Obtaining metaphase cells for chromosome analysis requires the use of a series of reagents, protocols, and environmental conditions, among others, that will allow us to collect the chromosomes. Metaphase cells must be cultured under certain conditions in order to obtain a proper number of dividing cells, which need to grow and divide fast in this medium as well. Taking into account all the issues mentioned above, an accurate knowledge from the culture medium and its conditions, as well as the techniques and protocols required in 
general, will allow a good cell growth in the culture and the collection of chromosome spreads to carry out the cytogenetic characterization and the identification of chromosomal abnormalities present in the cells in study.

This chapter describes the practical aspects of performing cytogenetic studies in primary cultures and human cancer cell lines that have been previously standardized, in order to be applied not only in research but in diagnosis and possible treatment of several diseases.

\section{Generalities}

The application of cytogenetic studies on tissue and cancer cell lines has become important in recent years, because the presence of some chromosomal abnormalities indicate the prognosis of the disease and the corresponding response to therapy. The most common clinical applications of cytogenetic studies on tissue and cancer cell lines are:

- Establishing the type of chromosomal abnormalities and its frequency

- Identifying the genes located in the affected chromosomal regions in order to establish those possibly implied in neoplasia

- Studying tumorigenic and metastatic behaviors, apoptosis and functionality

- Identifying the mechanisms of action used by hormones

- Establishing models for drug resistance studies

- Establishing the therapeutic potential of different treatments

- Supporting further research.

The knowledge of novel chromosome rearrangements and breakpoints identified could be useful for further molecular, genetic and epigenetic studies on human cancer that could lead us to understand the mechanisms involved in the development and progression of this disease.

\subsection{Characteristics of cell cultures}

Cell cultures can be divided into two groups, depending on the substrate used for cell growth:

- Suspension cultures: Cells are cultured by constant agitation in a liquid medium. Cell cultures are prepared by diluting cell suspensions.

- Monolayer cultures: Cells adhere to a solid (glass or plastic) or semisolid (agar, blood clot) surface, forming a cell surface, which can be observed by light microscopy or phase contrast. Cultures are maintained by releasing cells from the substrate using mechanical or enzymatic procedures, continuing their life cycle in new cell subcultures.

\subsubsection{Requirement of cell growth}

There are several variables that determine whether a cell will multiply in vitro or not, some of these depend directly on the conditions of the growth medium and some do not.

- The growth medium must possess all the essential, quantitatively balanced nutrients. It must include all the necessary raw material to promote the synthesis of cellular macromolecules; it must also provide the substrate for metabolism (energy), vitamins and trace minerals (their primary function is catabolic) and a number of inorganic ions implied in the metabolic function. 
- Physiological parameters: temperature, $\mathrm{pH}$, osmolarity, redox potential, which must be kept within acceptable limits.

- Cell density and subculture mode

- Serum is added to the basal medium to stimulate cell multiplication and interaction with the other variables contained in the system. It serves as a source of macromolecular growth factors. Serum is a very effective supplement that promotes cell division because it contains different growth-promoting factors. Complete serum contains most of low molecular weight nutrients required for cell proliferation. Serum may neutralize trypsin and other proteases, provide a protein "carrier" to solubilize water-insoluble substances (such as lipids) and has the ability to provide hormones and growth factors to cells.

\subsubsection{Contamination of cell cultures}

Cell cultures can be contaminated by fungi, bacteria, mycoplasma, viruses, parasites or cells from other tissues. It is mistakenly thought that tissues obtained using aseptic techniques from apparently healthy animals are sterile; however, it is common to find bacteria, mycoplasma, viruses or other microorganisms in these tissues. Fungi and bacteria are universally distributed in nature and are relatively resistant to environmental factors such as temperature, radiation, and desiccation, among others.

These organisms can appear in cultures due to several factors:

- Through dust particles carried by air currents.

- Aerosols produced by the operator during handling.

- Through non-sterile equipment.

Viruses and mycoplasmas are found in nature mainly in cells and body fluids, and these are more sensitive than fungi and bacteria to environmental factors. The most important sources of contamination with mycoplasma are aerosols and sera used in culture mediums. Other routes of entry for the virus are other infected cell cultures, serum or spray. Three factors are determining the effectiveness of a sterility test:

- Sensitivity and spectrum of the medium used.

- Incubation terms and time.

- Sample Size

The medium used for these tests should be sensitive and have a broad spectrum to detect anaerobic bacteria, fungi and mycoplasmas in routine testing. Cultures for bacteria and mycoplasma should be incubated aerobically and anaerobically, in order to avoid the loss of detection of some microorganisms. It is recommended to test for sterility at different times in the initiation and harvesting of the cell culture (beginning, middle and end).

\subsubsection{Contamination of cell cultures by other cells}

A very common contamination, generally not considered by researchers working in cell culture, is cross-contamination between cell cultures, both at the intra and interspecific level (MacLeod et al., 1999; Marcovic \& Marcovic 1998; Masters et al., 2001; van Bokhoven et al., 2001; Masters 2002). Several cases of cross-contamination between cell cultures have been 
documented in the last years, this has been possible by some sources that are able to provide certified cell lines, which can be used when contamination in the cell culture is suspected. Approximately, a 20 to $30 \%$ of cell cultures are contaminated at the intra or interspecific level, and it is believed that this value is higher due to the large number of contaminated cultures, on which there is no suspicion. The most convenient way to avoid contamination is to use rigid sterilization and aseptic techniques, the culture medium must be proven for contamination before use, working with cell cultures in laminar flow chambers, decontaminate the work area on a daily basis and furthermore, when there is manipulation of different cell lines.

\subsection{Human cancer cell lines}

Many human carcinoma cell lines have been developed and are widely used for laboratory research, mainly in studies of tumorigenic and metastatic behaviors, apoptosis, functionality, and therapeutic potential, and particularly as in vitro models for cancer research. Among these cell lines are the following: MCF-7, SKBR3, TD47 and BT474.

\subsubsection{Characteristics}

MCF-7 is a cultured cell line from human breast cancer, which is widely used for studies on breast cancer biology and hormones' mechanism of action research. The cell line was originally derived at the Michigan Cancer Foundation from a malignant pleural effusion found in a postmenopausal woman with metastatic breast cancer. The cells express receptors as biological responses to a variety of hormones including estrogen, androgen, progesterone, glucocorticoids, insulin, epidermal growth factor, insulin-like growth factor, prolactin, and thyroid hormone with non-amplified HER2 status (Osborne et al., 1987)

The cell line SKBR3 is a highly rearranged, near triploid cell line, derived by Fogh and Trempe (1975) from a pleural effusion and overexpresses the HER2/c-erb-2 gene product. This cell line shows only a weak ESR2 (ERß) expression and no ESR1 (absence of functional ERa) and PGR expression, indicating that this cell line represents models of estrogen- and progesterone-independent cancers, with capability for local E2 formation and possible action via non-ER mediated pathways. ERß expression level in tumor cell lines is characterized by a significantly slowed proliferation (Hevir et al., 2011). ERß may negatively regulate cellular proliferation, promote apoptosis and thus may have not only a protective role in hormone-dependent tissues, such as breast and prostate, but also a tumor-suppressor function in hormone-dependent tissues (Lattrich et al., 2008).

Human breast ductal carcinoma BT474 cell line was isolated by Lasfargues et al (1978). It was obtained from a solid, invasive ductal breast carcinoma from a 60-year-old woman; cells were reported as tumorigenic in athymic mice and were found to be susceptible for mouse mammary tumor virus, confirmed as human with IEF from AST, GPDH, LDH and NP (Lasfargues et al., 1979).

T47D is a cell line derived from human ductal breast epithelial tumor, it was isolated from a pleural effusion obtained from a 54 year old female patient with an infiltrating ductal breast carcinoma (Keydar et al., 1979). These cells contain receptors for a variety of steroids and calcitonin. They express mutant tumor suppressor protein p53 protein. Under normal culturing conditions, these cells express progesterone receptor constitutively and are 
responsive to estrogen. They are able to lose the estrogen receptor (ER) during long-term estrogen deprivation in vitro. Culture conditions, receptor status, patient age and source and tumor type for each cell line are shown in Table 1 and Figure 1.

\begin{tabular}{|c|c|c|c|c|c|c|c|c|}
\hline $\begin{array}{l}\text { Cell } \\
\text { line }\end{array}$ & $\begin{array}{l}\text { Source } \\
\text { code }\end{array}$ & $\begin{array}{c}\text { Passage } \\
\text { no }\end{array}$ & $\begin{array}{c}\text { Receptor } \\
\text { status }\end{array}$ & $\begin{array}{l}\text { HER-2 } \\
\text { status }\end{array}$ & $\begin{array}{l}\text { Tissue } \\
\text { source }\end{array}$ & $\begin{array}{c}\text { Tumor } \\
\text { type }\end{array}$ & $\begin{array}{c}\text { Patient } \\
\text { age }\end{array}$ & $\begin{array}{l}\text { Culture } \\
\text { conditions }\end{array}$ \\
\hline \multirow{2}{*}{ T47D } & \multirow{2}{*}{$\begin{array}{c}\text { ATCC: } \\
\text { HTB-133 }\end{array}$} & \multirow{2}{*}{ P20 } & ER+ & \multirow{2}{*}{ Negative } & \multirow{2}{*}{ PE } & \multirow{2}{*}{ IDC } & \multirow{2}{*}{54} & \multirow{6}{*}{$\begin{array}{c}\text { RPMI } 1640+10 \% \\
\text { FBS + } 2 \text { mM L- } \\
\text { glutamine } \\
\text { +antibiotic- } \\
\text { antimycotic } \\
\text { solution (1X) }\end{array}$} \\
\hline & & & PR+ & & & & & \\
\hline \multirow{2}{*}{ MCF-7 } & \multirow{2}{*}{$\begin{array}{l}\text { ATCC: } \\
\text { HTB-22 }\end{array}$} & \multirow{2}{*}{ P16 } & ER+ & \multirow{2}{*}{ Negative } & \multirow{2}{*}{ PE } & \multirow{2}{*}{$\mathrm{AC}$} & \multirow{2}{*}{69} & \\
\hline & & & PR+ & & & & & \\
\hline \multirow{2}{*}{ SKBR3 } & \multirow{2}{*}{$\begin{array}{l}\text { ATTC: } \\
\text { HTB-30 }\end{array}$} & \multirow{2}{*}{ P15 } & ER- & \multirow{2}{*}{ Positive } & \multirow{2}{*}{ PE } & \multirow{2}{*}{$\mathrm{AC}$} & \multirow{2}{*}{43} & \\
\hline & & & PR- & & & & & \\
\hline BT474 & $\begin{array}{l}\text { ATTC: } \\
\text { HTB-20 }\end{array}$ & P12 & $\begin{array}{l}\text { ER+ } \\
\text { PR+ }\end{array}$ & Positive & IDC & IDC & 60 & $\begin{array}{l}\text { DMEM + 10\% } \\
\text { FBS + } 2 \mathrm{mM} \\
\text { glutamine + } \\
\text { antibiotic- } \\
\text { antimycotic } \\
\text { solution (1X) }\end{array}$ \\
\hline
\end{tabular}

Table 1. Characteristics of the breast cancer cell lines AC, adenocarcinoma; IDC, invasive ductal carcinoma; PE, pleural effusion; $\mathrm{P}$, passage number. Media conditions: FBS, fetal bovine serum; DMEM, Dulbecco's Modified Eagle's Medium. Cell lines were maintained at $37^{\circ} \mathrm{C}$ and $5 \% \mathrm{CO} 2$ in the indicated media

\subsubsection{Cytogenetic abnormalities found in human cancer cell lines}

MCF-7 cell line has a modal number from 82 to 86 with 56 types of aberrations: 28 numerical and 28 structural aberrations. The most common aberrations in MCF-7 cells are der (19) $t$ $(12 ; 19)(q 13 ; q 13.3)$ and add(19)(p13) (Figure 2A).

SKBR3 cell line has a modal number from 71 to 83 , with 48 types of rearrangements: 27 numerical and 21 structural rearrangements. The most common aberrations in this cell line are $\operatorname{del}(1)(1 \mathrm{p} 13)$ and add(17)(17q25) (Figure 2B).

BT474 cell line demonstrated to have a modal number from 65 to 106, with 67 different rearrangements: 35 numerical and 32 structural aberrations. The most common aberrations in this cell line are: Additional material of unknown origin on chromosome 14: $\operatorname{add}(14)(q 31)$, derivatives from chromosomes $6: \operatorname{der}(6) \mathrm{t}(6 ; 7)(\mathrm{q} 25 ; \mathrm{q} 31)$ and 11: $\operatorname{der}(11) \mathrm{t}(8 ; 11 ; ?)(\mathrm{q} 21.1 ; \mathrm{p} 15 ; ?)$, losses in chromosomes 15, 22 and $\mathrm{X}$ chromosome and a gain on chromosome 7 (Figure 2C).

T47D cell line have a modal number of 57 to 66 , with 52 types of rearrangements: 26 numerical and 26 structural. The most common aberrations in this cell line are: $\operatorname{der}(X) t(6 ; X)(q 12 ; p 11) ; \quad \operatorname{der}(8 ; 14)(q 10 ; q 10) ; \quad \operatorname{del}(10)(p 11.2) ; \quad \operatorname{der}(16) t(1 ; 16)(q 12 ; \mathrm{q} 12)$ $\operatorname{dup}(1)(\mathrm{q} 21 \mathrm{q} 43)$ and $\operatorname{der}(20) \mathrm{t}(10 ; 20(\mathrm{q} 21 ; \mathrm{q} 13.3)$ Figure 2D. The cell lines SKBR3 and BT474 exhibited amplification of HER-2 gen by FISH and the cell lines MCF-7 and T47D not have amplification for this gene. 

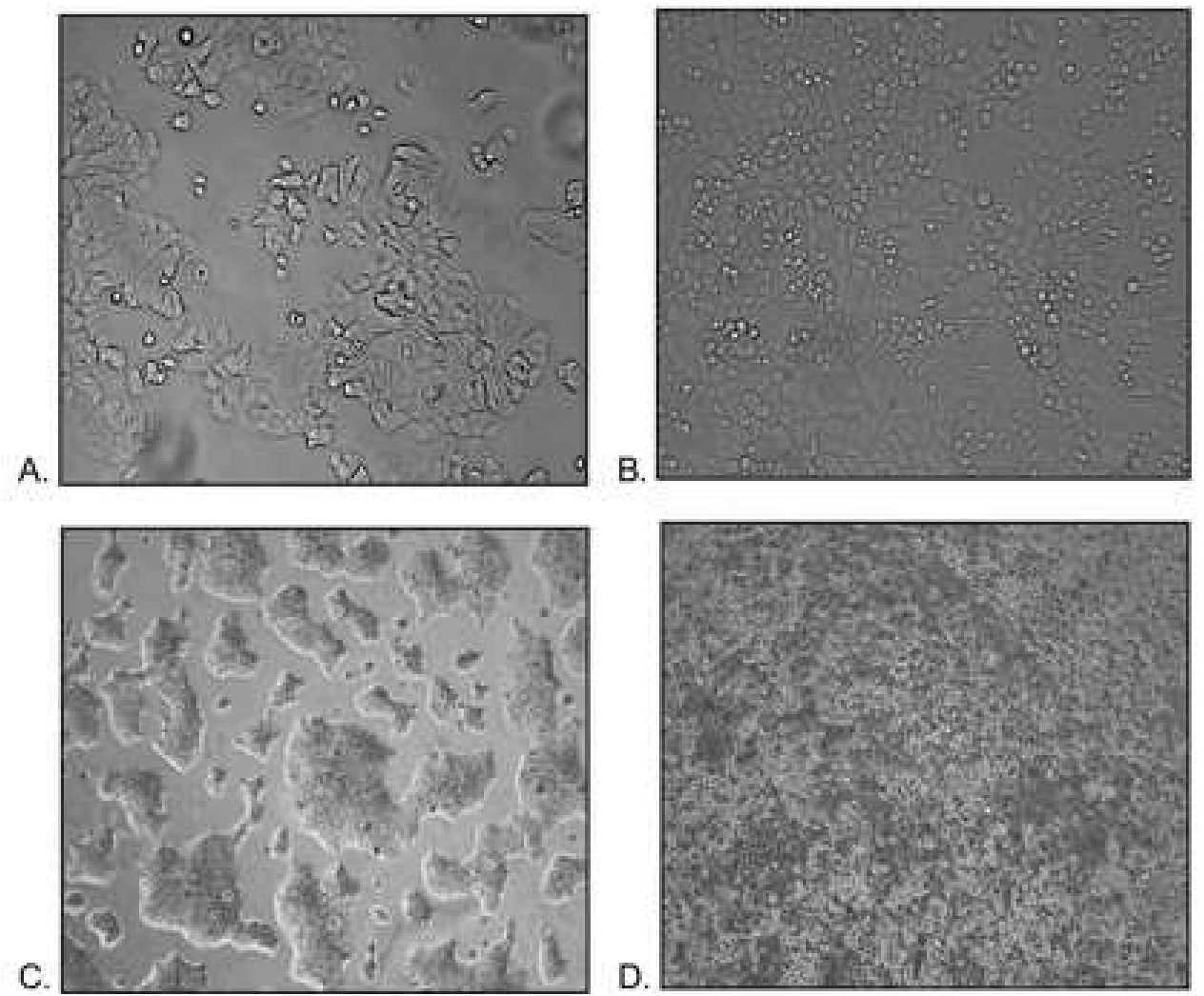

Fig. 1. Inverted microscopic pictures of representative breast cancer cell lines in a monolayer culture. A) MCF-7; B) SKBR3; C) BT474; D) T47D

\section{Cytogenetic techniques from tumoral tissue samples and cancer cell lines}

Obtaining metaphase cells for chromosome analysis requires the use of a series of reagents that will allow us to collect the chromosomes. Metaphase cells must be grown in vitro under certain conditions in order to obtain a proper number of dividing cells. Cells used for chromosome collection must be able to grow and divide fast in the culture medium. Different types of cells may require specific growth factors and medium supplements; once the basic requirements for each cell type are known, the appropriate culture medium is selected, checking sterility appropriately. After the culture has reached the $80 \%$ of confluence, it must be harvested and fixed to make a cytogenetic suspension. Cultures are growth arrested and accumulated in metaphase or prometaphase by inhibiting tubulin polymerization and thus preventing the formation of the mitotic spindle (e.g., using colcemid or velbe). Following exposure to colcemid or velbe, cells are treated with a hypotonic solution to enhance the dispersion of chromosomes and fixed with carnoy fixative (Methanol: Acetic Acid). Once fixed, the cytogenetic preparation can be stored in cell pellets, under fixative conditions and $20^{\circ} \mathrm{C}$ for several months. Fixed cells are spread on slides and air-dried, to be finally banded for the correct identification of chromosomes. Obtaining an 

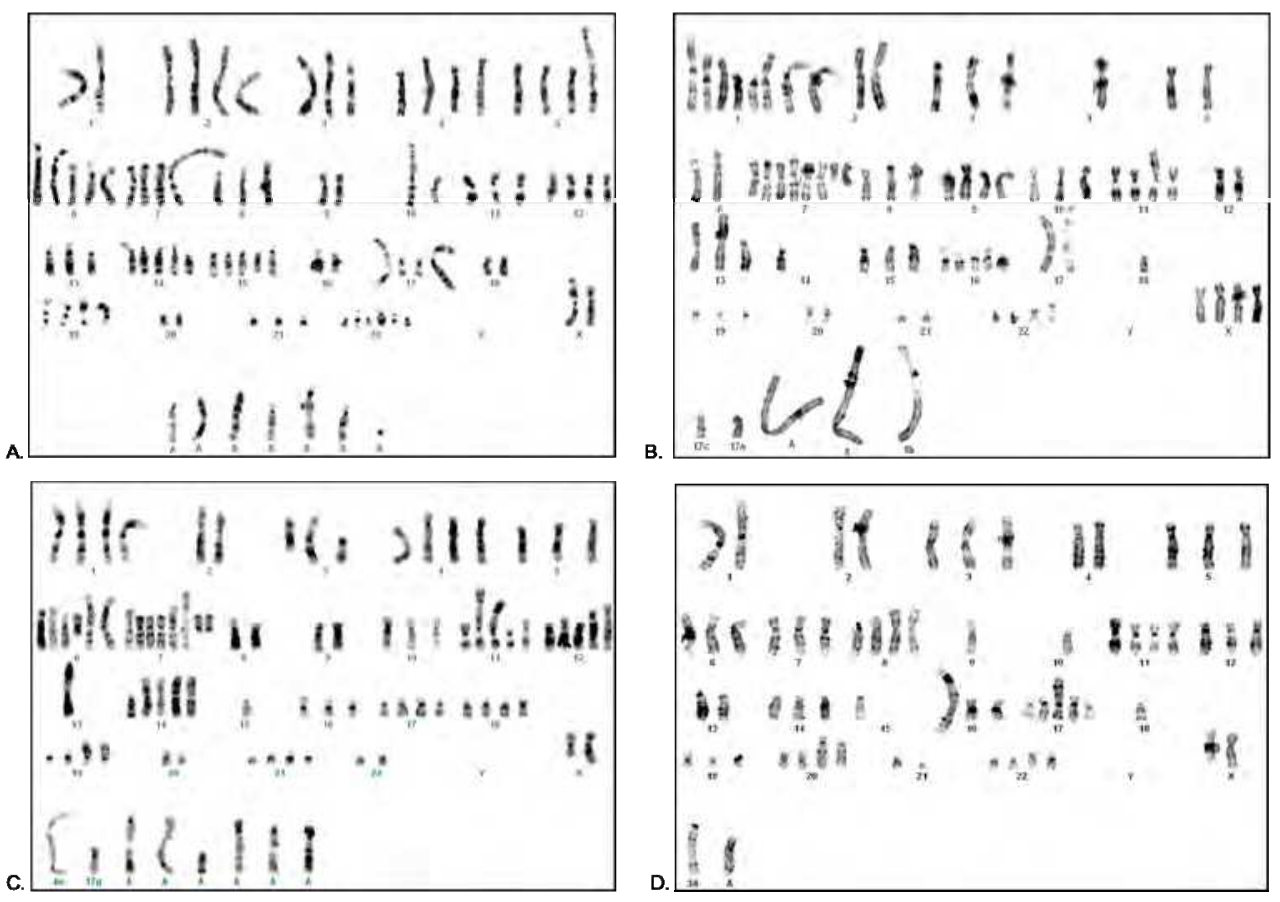

Fig. 2. Karyotypes from breast cancer cell lines. A) MCF-7; B) SKBR3; C) BT474; D) T47D15$\mathrm{ml}$ conical centrifuge tube

adequate quality on chromosome spreads is multifactorial; this will be discussed in detail further on. The amount of metaphases obtained is sometimes inadequate for chromosome analysis, thus it is always necessary to keep growing the cell line.

\subsection{Materials, reagents and equipment}

\subsubsection{Equipment}

- Laminar flow chamber

- Incubator

- CO2 Incubator

- Serological bath

- Centrifuge

- Refrigerador

- Microscope with camera

- Inverted microscope

- Magnetic Stirrer

- Micropipettes

- Analytical balance

- Vacuum Pump 


\subsubsection{Materials}

- $\quad 75-\mathrm{cm}^{2}$ tissue culture flasks

- $\quad 25-\mathrm{cm}^{2}$ tissue culture flasks

- $\quad$ Sterile disposable plastic transfer pipettes

- Glass slides

- Coverslip sheets

- Petri dishes

\subsubsection{Reagents}

Solutions should be kept in the dark at $-20^{\circ} \mathrm{C}$ or $4^{\circ} \mathrm{C}$, according to the manufacturer's instructions. According to frequency of use, reagents should be aliquoted and frozen. Reagents should be thawed before use and stored at $4^{\circ} \mathrm{C}$. Frequent freezing and unfreezing may cause alteration of the culture medium by inactivating the components.

Medium: The most commonly used medium for cell cultures are Dulbecco's modified Eagle's medium-DMEM, RPMI 1640 and DMEM-F12, among others. If the medium does not contain Glutamine, L-glutamine should be added (final concentration $2 \mathrm{mM}$ ); this is an essential amino acid that is unstable and has a short life at room temperature. To each 500 $\mathrm{ml}$ bottle of medium, add $50 \mathrm{ml}$ of Fetal Bovine Serum, $5 \mathrm{ml}$ of L-Glutamine $(200 \mathrm{mM})$ and 5 $\mathrm{ml}$ of antibiotic-antimycotic solution (100x). Store the medium up for a month at $4^{\circ} \mathrm{C}$. In order to establish primary cultures it is recommended to add also hydrocortisone, estradiol and insulin to the culture medium, providing enough nutrients to induce cell growth.

Serum: Fetal bovine serum; the proportion commonly added is $50 \mathrm{ml}$ of serum per each 450 $\mathrm{ml}$ of medium. Usually, the presentation of fetal bovine serum is $500 \mathrm{ml}$, so this amount should be aliquoted in $50 \mathrm{ml}$ aliquots which must be stored at $-20^{\circ} \mathrm{C}$ and thawed at $4^{\circ} \mathrm{C}$ or room temperature prior to use. It is advisable not to thaw the medium at high temperatures $\left(37^{\circ} \mathrm{C}\right.$ or more), as this could alter its composition.

Collagenase stock solution: Type 2 collagenase. To make the stock solution, dissolve 215 $\mathrm{U} / \mathrm{mg}$ collagenase in distilled water to obtain a final concentration of $2000 \mathrm{U} / \mathrm{ml}$, filter the solution through a $0.2-\mu \mathrm{m}$ filter and prepare $1 \mathrm{ml}$ aliquots, these can be kept stored for 2-3 months at $-20^{\circ} \mathrm{C}$. The working solution of $200 \mathrm{U} / \mathrm{ml}$ is prepared immediately before use, adding $1 \mathrm{ml}$ collagenase each $9 \mathrm{ml}$ of complete medium. This solution should be kept at $4^{\circ} \mathrm{C}$.

\section{Arresting agents:}

Colcemid: Colchicine inhibits microtubule assembly by binding to a high affinity site on $\beta$ tubulin. Colchicine binding occurs in a nearly irreversible manner and exerts a conformational change in tubulin, as well as in colchicine itself. (Daly, et al. 2009). Colcemid is used on cell lines displaying a high-speed replication and is applied to a final concentration of $0,01 \mu \mathrm{g} / \mathrm{ml}$ for 2.5 hours.

Velbe: Described as a vinca alkaloid, also called vinblastine, this agent is derived from the periwinkle plant, Catharanthus roseus, and is noted as the most successful anticancer agent within the past few years. Binding of the vinca alkaloids to $\beta$-tubulin occurs fast and reversibly at an intermolecular contact point (Daly, 2009). It is recommended to use Velbe if the rate of cell replication is low at a final concentration of $0,01 \mu \mathrm{g} / \mathrm{ml}$ in a maximum of 16 hours. 
The application of these reagents can arrest cells in metaphase and helps chromosomes contraction, allowing an easy recognition of these cells in pro-metaphase or metaphase. The use, exposure time and Colcemid or Velbe concentration varies and depends on several factors, including cell type and overall growth characteristics.

Hypotonic solution: Saline solution that allows chromosomes dispersion within the cell membrane, facilitating its observation and recognition. In order to obtain chromosome preparations from cell lines, the following hypotonic solutions can be used; the selection of this solution will depend on the degree of chromosome condensation obtained.

$0.075 \mathrm{M}$ potassium chloride $(\mathrm{KCl})$ : Use $5.59 \mathrm{~g} \mathrm{KCl}$ and make up to 1 liter of aqueous solution. Use the solution at $37^{\circ} \mathrm{C}$.

$20 \mathrm{mM}$ potassium chloride $(\mathrm{KCl})$ and $10 \mathrm{mM}$ sodium citrate $\left(\mathrm{Na}_{3} \mathrm{C}_{6} \mathrm{H}_{5} \mathrm{O}_{7}\right)$ : Use $1 \mathrm{~g} \mathrm{KCl}$ and $1 \mathrm{~g}$ sodium citrate and make up to $500 \mathrm{ml}$ of aqueous solution. Use the solution at $37^{\circ} \mathrm{C}$. Its use is recommended with longer chromosomes, that may be twisting or overlapping.

Fixative: Reagent used to stop the action of hypotonic solutions and which in turn, has several functions throughout the procedure related to hemolysis, dehydration, chromosomes fixation and removal of debris membrane that may interfere with the chromosome extended. This reagent is prepared with three parts of absolute methanol and one part of glacial acetic acid. This should be freshly prepared just before its use and should be kept always cold $\left(-20^{\circ} \mathrm{C}\right)$.

10x Trypsin-EDTA: Stored frozen in $1 \mathrm{ml}$ aliquots. Diluted 1:10 in PBS when required to obtain a $1 \mathrm{x}$ working solution. Store indefinitely at $4^{\circ} \mathrm{C}$. Place at room temperature or $37^{\circ} \mathrm{C}$ before use.

Phosphate-buffered saline (PBS): $\mathrm{pH}$ 7, used for diluting solutions.

\section{Stains:}

Wright's stain: This stain is usually obtained as a powder. Cover a flask with aluminum foil and insert a magnetic stirrer. Add $0.5 \mathrm{~g}$ stain and $200 \mathrm{ml}$ methanol. Stir for $30 \mathrm{~min}$. Filter using a filter paper into a foil-coated bottle. Close the lid tightly and store the bottle in a dark cupboard for at least a week before its use. The stain should be diluted immediately before use at 1:4 with $\mathrm{pH} 6.8$ buffer.

Giemsa: This stain is usually obtained as a liquid. Before use, the following mixture must be prepared: $0.2 \mathrm{ml}$ Giemsa, $0.2 \mathrm{ml}$ Sorensen Tampon and $4.6 \mathrm{ml}$ water (the amount used to dye a slide).

Saline-sodium citrate (SSC) buffer: This is a widely used weak buffer, which is used to carry out several washes and to control stringency during in situ hybridization. The 20x stock solution consists in mixing $3 \mathrm{M}$ sodium chloride and $300 \mathrm{mM}$ trisodium citrate. To make the stock, dissolve $38,825 \mathrm{~g}$ sodium chloride $(\mathrm{NaCl})$ and $22.05 \mathrm{~g}$ sodium citrate $\left(\mathrm{Na}_{3} \mathrm{C}_{6} \mathrm{H}_{5} \mathrm{O}_{7} .2 \mathrm{H}_{2} \mathrm{O}\right)$ in $200 \mathrm{ml}$ of water. Adjust to $\mathrm{pH} 7$ with $\mathrm{NaOH}$ or $\mathrm{HCl}$ if necessary, make up to $250 \mathrm{ml}$ and sterilize by autoclaving procedures.

Sorensen Buffer: This buffer is used for G-Banding. The working solution consists in two solutions: $\mathrm{KH}_{2} \mathrm{PO}_{4}$ and $\mathrm{Na}_{2} \mathrm{HPO}_{4}$. Prepare the buffer as follows:

- $\quad$ Sln A: $\mathrm{KH}_{2} \mathrm{PO}_{4}$. Dissolve 4559 grs in $500 \mathrm{ml}$ of sterile distilled water 
- $\quad$ Sln B: $\mathrm{Na}_{2} \mathrm{HPO}_{4}$. Dissolve 4755 grs in $500 \mathrm{ml}$ of sterile distilled water.

- $\quad$ Take $500 \mathrm{ml}$ of solution A and mix it with $496.8 \mathrm{ml}$ of solution B, keep it at $4^{\circ} \mathrm{C}$.

$\mathbf{H C l} 0,2 \mathrm{~N}$ : Used for G-Banding. To prepare $1000 \mathrm{ml}$ of solution, add 8,25 $\mathrm{ml} \mathrm{HCl} \mathrm{37 \%} \mathrm{and}$ $500 \mathrm{ml} \mathrm{H}_{2} \mathrm{O}$ into a glass container. Store at room temperature.

\subsection{Cell culture methods from tumoral tissue}

To ensure cell growth and obtain cells in metaphase, it is important to take into account all the sampling conditions. Sterile, non-necrotic tumor samples must be collected in a transport container using optimal conditions of sterility; for example, a sterile tube containing sterile culture medium, an antimycotic and a double concentration of antibiotics, which should be transported to laboratory facilities under controlled temperature.

The tissue sample must be representative, sterile, and viable. To ensure fast cellular growth and prevent contamination with other cell types, the cultures must be incubated in a small culture flask $\left(25 \mathrm{~cm}^{2}\right)$ or directly on microscopic slides mounted in multi-well chambers. Cell attachment, proliferation, and mitotic rate should be monitored by daily $\mathrm{x}$ examination through an inverted microscope.

The steps to obtain metaphases are:

3.2.1 Dissociation of solid specimen: Enzymatic and mechanical procedures

3.2.2 Culture initiation

3.2.3 Culture harvesting and metaphases

3.2.4 Banding techniques

3.2.5 Freezing of viable cells

The way of determining the time of harvest, colchicine use and exposure to hypotonic solution will depend on the cell type and its growth rate.

\subsubsection{Dissociation of solid specimen}

Materials

- Collagenase $(2000 \mathrm{U} / \mathrm{ml})$

- Appropriate culture medium (RPMI 1640, DMEM-F12) containing 10\% fetal bovine serum (FBS), antibiotic-antimycotic solution (1X), L-glutamine (2 mM), Hydrocortisone, $17 \beta$-estradiol and insulin.

- $\quad$ PBS (1X)

- $\quad 25-\mathrm{cm}^{2}$ tissue culture flasks

- $\quad 15-\mathrm{ml}$ conical centrifuge tube

- 5-ml and 10-ml plastic pipettes

- Petri dishes

- Microscopic slides mounted in multi-well chambers x 6 wells

- Tissue dissection equipment: tweezers, scissors

Procedure

Mechanical Disaggregation (Figure 3) 

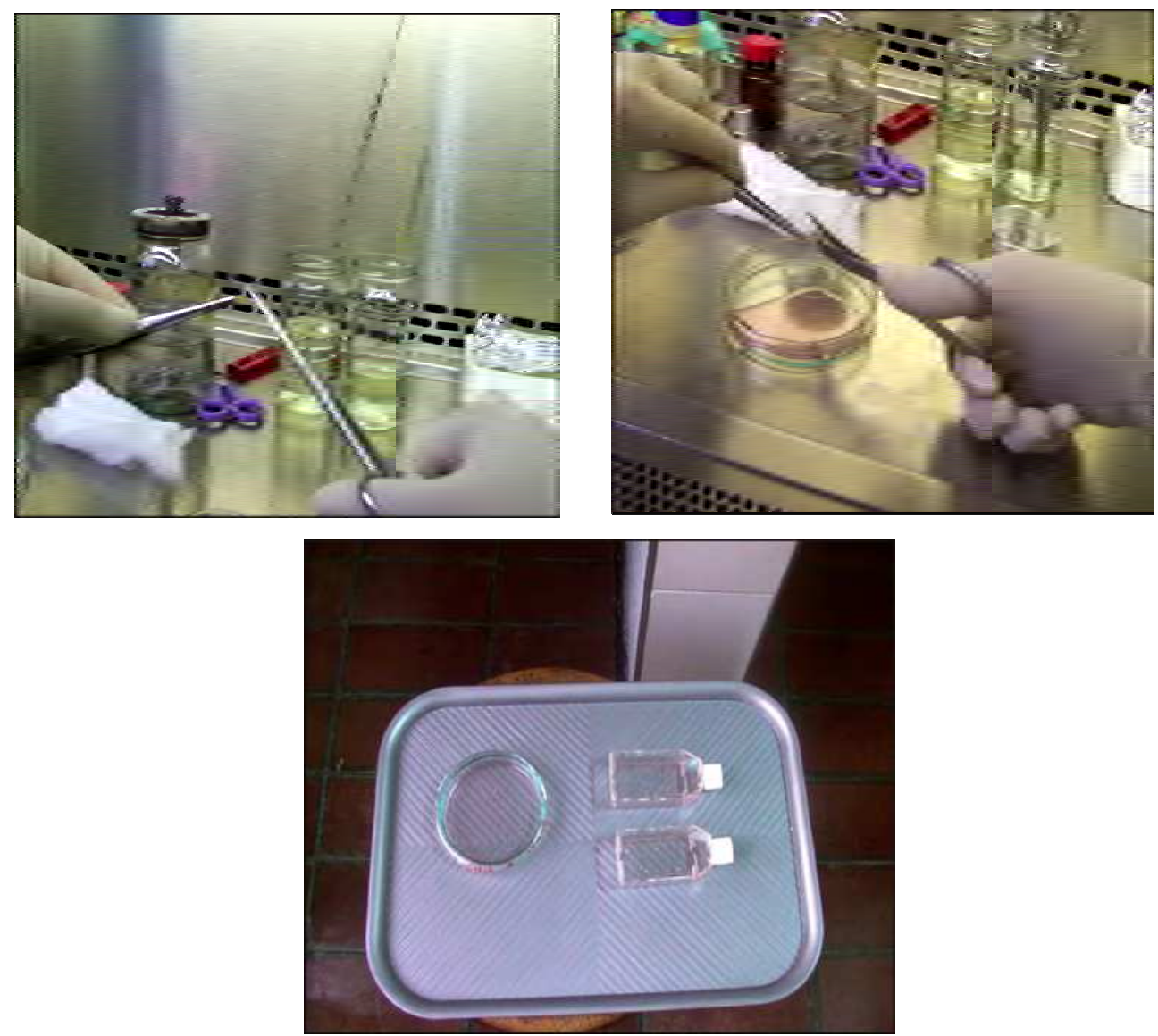

Fig. 3. Representative pictures of tissue cultures, indicating the steps for mechanical dissociation of tissue

- Remove the specimen from the transport container and place it immediately into petri dishes, using $5 \mathrm{ml}$ PBS containing antibiotic and antimycotic agents, in order to wash the tissue.

- Take the tissue and transfer it to another petri dish containing $2 \mathrm{ml}$ of medium; afterwards, remove fat, necrotic tissue and/or blood that may interfere with cell growth.

- Using scissors and tweezers, cut the tissue into fragments of 1-2 $\mathrm{mm}$ in size.

- Transfer some of the fragments to a petri dish for enzymatic digestion.

- Take the other fragments and distribute them into $25 \mathrm{~cm}^{2}$ plastic flasks containing $3 \mathrm{ml}$ of culture medium or in microscopic slides mounted in multiwell chambers $\times 6$ wells containing $1 \mathrm{ml}$ of medium, using glass Pasteur pipettes.

- Place flasks on their sides in an incubator at $37^{\circ} \mathrm{C}$ in $5 \% \mathrm{CO}_{2}$, incubate for $2-3$ days. 


\section{Enzymatic Digestion}

- Using the tissue fragments previously deposited in petri dishes for enzymatic digestion, add 2-3 ml medium containing collagenase at a final concentration of $200 \mathrm{U} / \mathrm{ml}$.

- Incubate at $37^{\circ} \mathrm{C}$ in $5 \% \mathrm{CO} 2$ for $16-24 \mathrm{~h}$ (overnight), stirring occasionally.

The times used for enzymatic treatment depends on the type of tumor, but generally an overnight incubation is enough. Check disaggregation process under the inverted microscope. A large number of single cells and small clusters of cells may be observed floating at the end of this period.

- After this time, inactivate the enzyme by adding $2 \mathrm{ml}$ of fetal bovine serum (FBS), applied directly to the sample, and transfer the cell suspension to a 15-ml conical centrifuge tube

- Centrifuge for $10 \mathrm{~min}$ at $1000 \mathrm{rpm}$, discard the supernatant.

- Add fresh medium to the tube, mix the suspension by pipetting up and down and transfer the cell suspension to a 25- $\mathrm{cm}^{2}$ tissue culture flask or to a multiwell chambers $x 6$ wells

- Incubate at $37^{\circ} \mathrm{C}$ in $5 \% \mathrm{CO} 2$ to allow cells that were attached to the plastic base to grow during the collagenase treatment.

\subsubsection{Culture initiation}

Materials

- $\quad$ Appropriate culture medium (RPMI 1640, DMEM-F12) containing 10\% fetal bovine serum (FBS), antibiotic-antimycotic solution (1X), L-glutamine (2 mM), Hydrocortisone, $17 \beta$-estradiol and insulin

- $\quad$ PBS (1X)

- $\quad$ 5-ml and 10-ml plastic pipettes

Procedure

- After an incubation period of 24 hours, monitor the cell cultures (both those who were and were not disaggregated enzymatically). Examine the culture using phase-contrast microscopy to assess the extent of tissue adhesion and cell growth.

- In a laminar flow chamber and under strict conditions of asepsis and sterility, remove the medium containing unattached cells and cellular debris from flasks using a glass Pasteur pipette

- $\quad$ Add gently $2 \mathrm{ml}$ PBS to wash and remove fragments attached; afterwards, remove PBS.

- $\quad$ Add 4-5 $\mathrm{ml}$ of the medium and incubate again.

Examine flasks and the multiwell chambers daily through an inverted microscope in order to establish cell growth and mitotic activity. Once cell cultures reach the $80 \%$ of confluence, these can be processed to obtain metaphases. Figure 4.

Note: The culture of both fragments (both those dispersed enzymatically and the cell suspension after the enzyme digestion) will ensure cell growth, since in some cases cell growth obtained from cell suspension is insufficient to obtain metaphases

\subsubsection{Harvesting of culture and metaphases for chamber slides}

In a chamber slide the cells are not removed from the growing surface, is important to control cell confluence, this can not be greater than $80 \%$ before the addition of colchicine, 

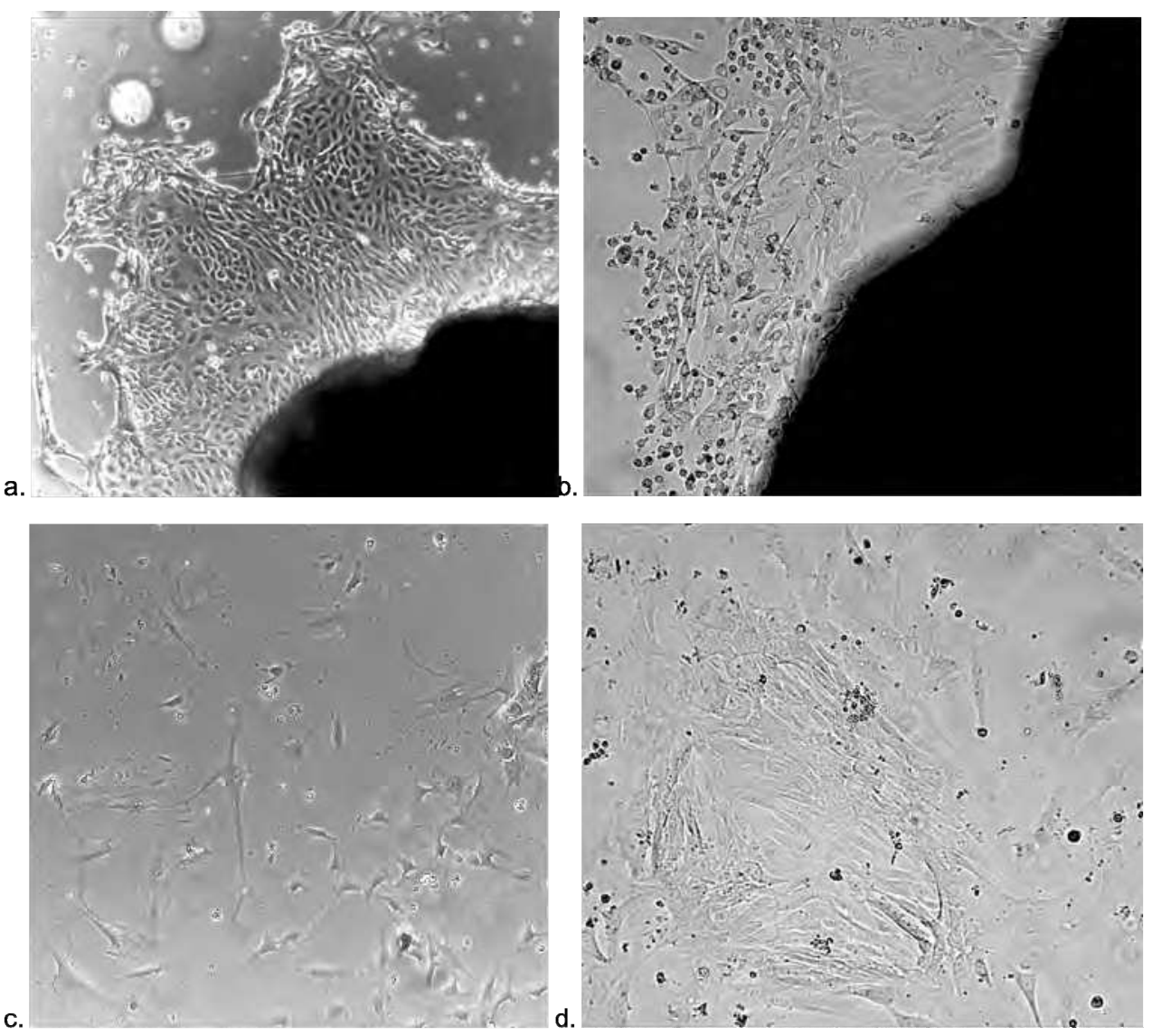

Fig. 4. Pictures of solid tumor in culture. $(a, b)$ Cell growth observed around fragments that were disaggregated only by mechanical procedures, after 6 days of culture $(4 x-10 x) .(c, d)$ Cell growth obtained after enzymatic disaggregation, after 8 days of culture $(4 x-10 x)$. A good cell growth was observed in both cell cultures; hence, it is advisable to prepare cell cultures using both methods: enzymatically disaggregated fragments and fragments that were mechanically disaggregated only.

since greater confluence is difficult to obtain a good number of metaphases. Colcemid is added to the culture at a final concentration of $0.01 \mu \mathrm{g} / \mathrm{ml}$ for 3 hours.

\section{Materials}

- $20 \mathrm{mM}$ potassium chloride $(\mathrm{KCl})$ and $10 \mathrm{mM}$ sodium citrate $\left(\mathrm{Na}_{3} \mathrm{C}_{6} \mathrm{H}_{5} \mathrm{O}_{7}\right)$

- $\quad$ Fixative methanol-acetic acid (3:1)

- Pasteur pipette

Procedure

- Carefully remove the medium with a Pasteur pipet. 
- Add $2 \mathrm{ml}$ of prewarmed hypotonic solution $(20 \mathrm{mM}$ potassium chloride $(\mathrm{KCl})$ and 10 $\mathrm{mM}$ sodium citrate $\left.\left(\mathrm{Na}_{3} \mathrm{C}_{6} \mathrm{H}_{5} \mathrm{O}_{7}\right)\right)$ slowly down the side of the chamber and put into incubator at $37^{\circ} \mathrm{C}$ for $17 \mathrm{~min}$.

- $\quad$ Remove the cultures of the incubator and carefully add, around of the well, $1 \mathrm{ml}$ of cold freshly prepared fixative methanol-acetic acid (3:1) for 10 minutes

- Remove all fluid and add $2 \mathrm{ml}$ of fresh cold fixative slowly down the side of the well for 20 minutes.

- $\quad$ Remove the fixative and add new fixative as in the previous step, repeat this step once more

- Finally, slowly remove the microscopic slide of the multiwell plate and put it on a slide. Air-dry the slides at room temperature. Check spreading under phase-contrast microscope.

\subsubsection{Harvesting procedures for flasks}

This protocol will be considered later, in the description for the one used to obtain chromosome preparations from cell lines, since the procedure is the same (Protocol 3.3.2).

\subsubsection{Banding techniques}

There are several possibilities for G-banding; we will refer here two of the ones widely used for chromosome analysis. Its implementation depends on the laboratory conditions and standardization. The difference between them is the use of a reagent that allows the degradation of chromosomal proteins (trypsin or $\mathrm{HCl}$ ) and the dye (Wright or Giemsa).

\section{Protocol 1}

Materials

- $\quad 0,2 \mathrm{~N} \mathrm{HCl}$

- 2 XSSC Buffer, prewarmed at $65^{\circ}$ in a water bath

- Wright's stain

- Sorense Buffer Tampon

- Disposal plastic pipettes

- Coupling Glass

Procedure

- Heat the slides in an oven at $70^{\circ} \mathrm{C}$ for 24 hours

- $\quad$ Remove the slides from the oven, leave for cooling and add 1-2 $\mathrm{ml} 0.2 \mathrm{~N} \mathrm{HCl}$ on each slide for 2 minutes, using a Pasteur pipette

- $\quad$ Remove the $\mathrm{HCl}$ and thoroughly rinse with distilled water, let dry.

- Place carefully the slides in 2xSSC buffer, preheated at $65^{\circ} \mathrm{C}$ for 4 minutes.

- Remove the plates from the buffer and wash thoroughly with distilled water, let dry.

The time in $\mathrm{HCl}$ and in buffer depends on the type of cell; these times have been standardized for certain cell lines. If you do not get a good banding, you should standardize the time of exposure to these reagents.

- $\quad$ Dye the slides by adding 1-2 $\mathrm{ml}$ of Wright's dye solution on each slide, for 3 minutes. 
Wright's stain solution is prepared by mixing $1 \mathrm{ml}$ of Wright's stain with $3 \mathrm{ml}$ of Sorensen buffer; this amount should be enough to dye 2 or 3 slides.

- $\quad$ Remove the stain and wash thoroughly with distilled water.

- View under a microscope to evaluate the banding quality.

- Cover slides with coverslips and seal them with Entellan to protect and preserve the chromosome spreads.

\section{Protocol 2}

\section{Materials}

- $\quad$ Trypsin $0.25 \%$

- $2 x S S C$ Buffer, prewarmed at $60^{\circ}$ in a water bath

- Giemsa stain

- Sorense Buffer tampon

- Disposal plastic pipettes

- Coupling Glass

Procedure

- Dehydrate the slides in an oven at $80^{\circ} \mathrm{C}$ for 4 hours

- Remove the slides from the oven and carefully, place the slides in 2xSSC buffer preheated at $60^{\circ} \mathrm{C}$ for 30 minutes

- Remove the slides from the buffer and wash thoroughly with distilled water, let dry.

- Introduce the slides in the coupling glass containing a cold solution of trypsin with water (1:1) for 5 seconds

The trypsin stock solution for G-banding is at a concentration of $0.25 \%$. The working solution consists of a 1:1 mixture with cold distilled water. This solution must be kept at $4^{\circ} \mathrm{C}$, at this temperature best results are obtained.

- $\quad$ Remove the slides from trypsin and wash thoroughly with distilled water, let dry.

The time in trypsin depends on the type of cell; these times have been standardized for certain cell lines. If you do not get a good banding, you should standardize the time of exposure to these reagents. For best results, trypsin should always be kept cold and plates should remain hot. Once hot slides are introduced into cold trypsin, thermal shock can deliver better results. The slides can stay warm if these are placed around a hot plate

- $\quad$ Dye the slides by adding 1-2 $\mathrm{ml}$ of dye solution on each slide, for 10 minutes.

Giemsa stain solution is prepared by mixing 0,2 $\mathrm{ml}$ of Giemsa stain, 0,2 $\mathrm{ml}$ of Sorensen buffer and 4,6 $\mathrm{ml}$ of distilled water. This quantity is enough to dye 1 or 2 slides.

- Remove the stain and wash thoroughly with distilled water.

- View under a microscope to evaluate banding quality.

- Cover slides with coverslips and seal them with Entellan to protect and preserve the chromosome spreads.

If the chromosome spreads present a weak staining, Wright's or Giemsa solution can be added again for 2 minutes (Figure $5^{\mathrm{a}}$ ). If the bands are too light, it is suggested to reduce the time in HC or trypsin. It is also recommended to start banding only at a slide; this will 
delineate the conditions needed to obtain a good banding. A correct banding for chromosome analysis consists on light and dark bands, which are clearly defined and have a proper amount of color (Figure $5 b$ ).

Note: It is important to control humidity and temperature when carrying out the banding; if low temperatures and high humidity are present, it is difficult to obtain a good banding.

\subsection{Cell culture methods for cancer cell lines}

Cell lines must be transported to the laboratory on dry ice and optimal conditions of sterility. If possible, these should reach the laboratory frozen and be kept at $-20^{\circ} \mathrm{C}$. Established cell lines are generally obtained from sources such as the American Type Cell Collection (ATCC), which are well adapted to in vitro growth. The ATCC Cell Biology Collection is the most comprehensive and diverse of its kind in the world, consisting on over 3,600 cell lines from over 150 different species. Some of the cell lines offered by ATCC are listed in Table 2.

\subsubsection{Cell culture}

All the solutions and equipment that come into contact with cells must be sterile, and proper aseptic techniques must be used. It is recommended before beginning each procedure to leave the laminar flow chamber exposed to UV radiation for $15 \mathrm{~min}$. All cell culture incubations are carried out in a humidified incubator at $37^{\circ} \mathrm{C}$ and $5 \% \mathrm{CO}_{2}$.

\section{Materials}

- Appropriate culture medium (RPMI 1640 or DMEM), containing 10\% fetal bovine serum (FBS), antibiotic-antimycotic solution (1X) and L-glutamine (2 mM).

- $\quad 75-\mathrm{cm}^{2}$ tissue culture flasks

- $\quad 15-\mathrm{ml}$ conical centrifuge tube

- 5-ml and 10-ml plastic pipettes

Procedure

- Careful sterile techniques should be developed. Once in the laboratory, the cell line should be thawed in a serological bath at $37^{\circ} \mathrm{C}$, avoiding contact with the lid.

- In a laminar flow chamber, transfer rapidly the cell suspension to a $15-\mathrm{ml}$ conical centrifuge tube containing $5-10 \mathrm{ml}$ of medium with FBS.

- Centrifuge the cell suspension for $5 \mathrm{~min}$ at $1500 \mathrm{rpm}$ and room temperature.

- Pour off the supernatant; resuspend the cell suspension in $10 \mathrm{ml}$ of medium and transfer cells to a sterile $75-\mathrm{cm} 2$ culture.

- Place flasks on their sides in an incubator at $37^{\circ} \mathrm{C}$ and $5 \% \mathrm{CO}_{2}$ and leave them for $48 \mathrm{hr}$.

- At the end of incubation, examine the culture using phase-contrast microscopy to assess the extent of cell adhesion and cell growth.

- Change the culture medium and discard the culture medium existing. Add $5 \mathrm{ml}$ PBS (1x) (removes non-adherent cells), remove PBS and add $10 \mathrm{ml}$ of complete medium. Return flasks to incubator.

- Check cultures daily to determine the extent of adherence, cell growth and doubling time. The change of medium in cell cultures should take place every 48 hours, as previously indicated. 
a.

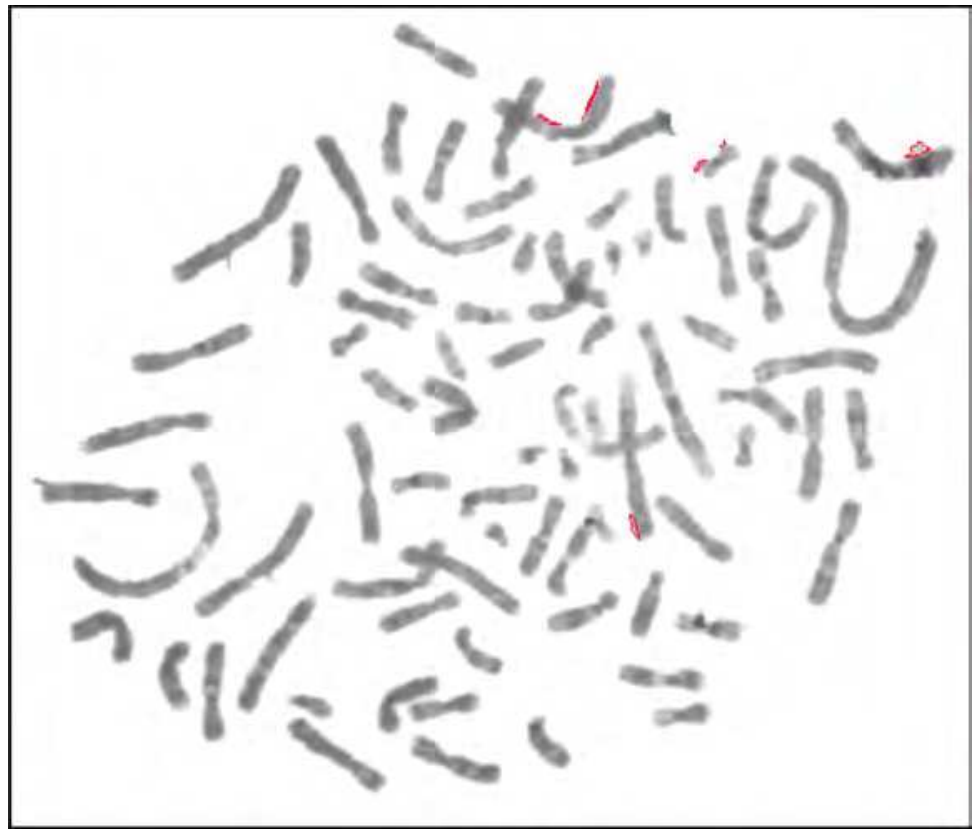

b.

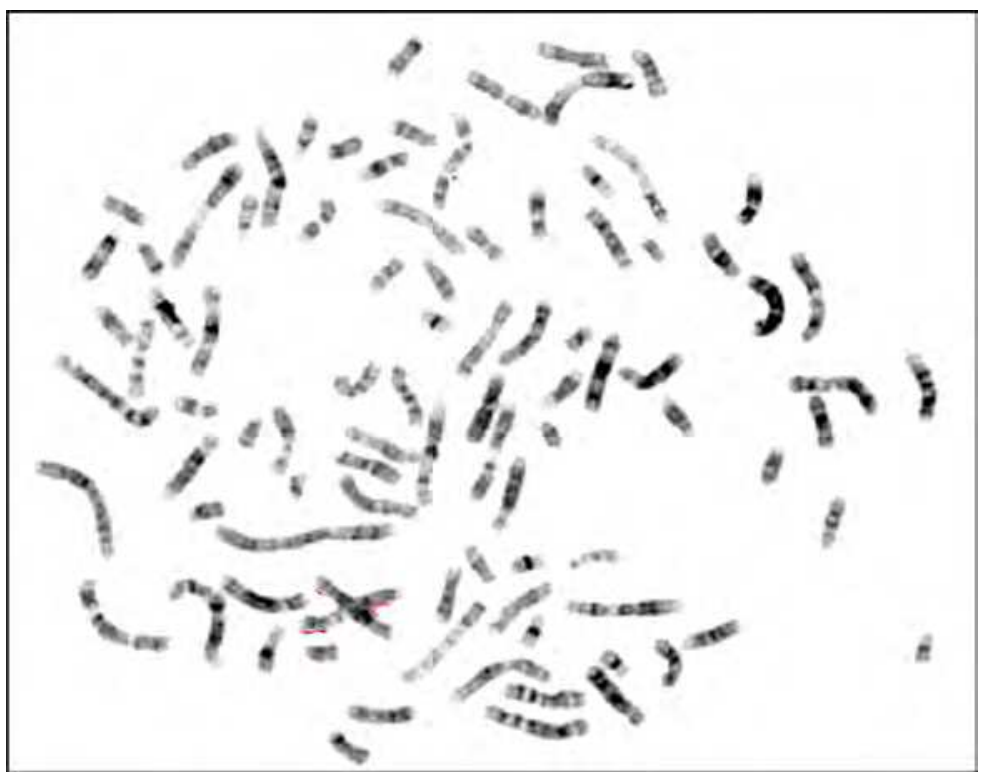

Fig. 5. G-Banded metaphase images (with and without correct banding) for chromosome analysis. (a) This metaphase shows very clear bands and homogeneously stained 
chromosomes, the bands are not visible. In this case, the time of incubation in $\mathrm{HCl}$ or trypsin must be modified (reduced). This metaphase is not appropriate for chromosome analysis.

(b) Light and dark bands in this metaphase are well defined and chromosomes have a proper staining; thus, these can be easily recognized. This metaphase is suitable for chromosome analysis.

\begin{tabular}{|c|c|c|}
\hline Cell Type & Cell Name (ATCC® No.) & Media \\
\hline Breast Adenocarcinoma & MDA-MB-231 (HTB-26) & Leibovitz's L-15 \\
\hline Breast Adenocarcinoma & MDA-MB-361 (HTB-27) & Leibovitz's L-15 \\
\hline Breast Adenocarcinoma & SKBR3 (HTB-30) & RPMI 1640 \\
\hline Breast Carcinoma & HCC1937 (CRL-2336) & RPMI-1640 \\
\hline Breast Adenocarcinoma & MCF-7 (HTB-22) & RPMI-1640 \\
\hline Breast Ductal Carcinoma & T47D (HTB-133) & RPMI-1640 \\
\hline Breast Ductal Carcinoma & BT474 (HTB-20) & DMEM \\
\hline Colon Adenocarcinoma & COLO 205 (CCL-222) & RPMI-1640 \\
\hline Colon Cancer & DLD-1 (CCL-221) & RPMI-1640 \\
\hline Colon Carcinoma & T84 (CCL-248) & DMEM:F-12 Medium \\
\hline Colon Carcinoma & CT26.WT (CRL-2638) & RPMI-1640 \\
\hline Cortical Neuron & HCN-1A (CRL-10442) & DMEM \\
\hline Gastric Carcinoma & NCI-N87 (CRL-5822) & RPMI-1640 \\
\hline Hepatoma & Hepa 1-6 (CRL-1830) & DMEM \\
\hline Kidney Fibroblast & COS-7 (CRL-1651) & DMEM \\
\hline Lung Adenocarcinoma & NCI-H441 (HTB-174) & RPMI-1640 \\
\hline Lung Adenocarcinoma & NCI-H1975 (CRL-5908) & RPMI-1640 \\
\hline Lung Adenocarcinoma & NCI-H23 (CRL-5800) & RPMI-1640 \\
\hline Lung Carcinoma & NCI-H1299 (CRL-5803) & RPMI-1640 \\
\hline Lung Carcinoma & NCI-H460 (HTB-177) & RPMI-1640 \\
\hline Lung Carcinoma & NCI-H292 (CRL-1848) & RPMI-1640 \\
\hline Mammary Tumor & 4T1 (CRL-2539) & RPMI-1640 \\
\hline Melanoma & B16-F10 (CRL-6475) & DMEM \\
\hline Melanoma & A375 (CRL-1619) & DMEM \\
\hline Pancreatic Beta Cells & Beta-TC-6 (CRL-11506) & DMEM \\
\hline Pancreatic Cancer & AsPC-1 (CRL-1682) & RPMI-1640 \\
\hline Pancreatic Carcinoma & BxPC-3 (CRL-1687) & RPMI-1640 \\
\hline Pancreatic Carcinoma & MIA PaCa-2 (CRL-1420) & DMEM \\
\hline Pancreatic Carcinoma & PANC-1 (CRL-1469) & DMEM \\
\hline Prostate Cancer & VCaP (CRL-2876) & DMEM \\
\hline Prostate Carcinoma & 22Rv1 (CRL-2505) & RPMI-1640 \\
\hline Prostate Carcinoma & LNCaP clone FGC (CRL-1740) & RPMI-1640 \\
\hline Renal Adenocarcinoma & 786-O (CRL-1932) & RPMI-1640 \\
\hline Retinal Epithelium & ARPE-19 (CRL-2302) & DMEM:F-12 Medium \\
\hline Rhabdomyosarcoma & RD (CCL-136) & DMEM \\
\hline
\end{tabular}

Table 2. Some Human Cancer Cell lines offered by ATCC 
- Once cell cultures reached the $80 \%$ of cell confluence, proceed with the protocol for the preparation of metaphase spreads

Note: Cells will be routinely monitored for mycoplasma contamination.

\subsubsection{Preparation of metaphase spreads}

In order to obtain metaphase spreads, cultures can be treated with Colcemid or Velbe (the use, exposure time and concentration of these arrest agents varies and depends on several factors, including cell type and overall growth characteristics), tripsinized, pelleted by centrifugation, hypotonically swollen and fixed. Incubation times depend on the type of cell. The hypotonically swollen and fixed cytogenetic suspension is then applied to glass slides and air-dried. To obtain good chromosomes spreading, the environment relative humidity should be of approximately $42 \%$, with a temperature of $27^{\circ} \mathrm{C}$. The slides are then ready for conventional or molecular cytogenetic analysis.

\section{Materials}

- Appropriate culture medium (RPMI 1640 or DMEM), containing 10\% fetal bovine serum (FBS), antibiotic-antimycotic solution (1X) and L-glutamine $(2 \mathrm{mM})$.

- $\quad 3,3 \mu \mathrm{g} / \mathrm{ml}$ Colcemid or $0,5 \mu \mathrm{g} / \mathrm{ml}$ Velbe

- Trypsin-EDTA (1x)

- $\quad$ PBS

- Hypotonic Solution: $0.075 \mathrm{M} \mathrm{KCl}$ or $20 \mathrm{mM} \mathrm{KCl}+10 \mathrm{mM}$ Sodium Citrate. Prewarmed to $37^{\circ} \mathrm{C}$ in oven or a water bath.

- $\quad 3: 1(\mathrm{v} / \mathrm{v})$ methanol/acetic acid fixative

- 15-ml conical centrifuge tube

- $\quad$ Sterile disposable plastic transfer pipets

- $\quad 75-\mathrm{cm}^{2}$ tissue culture flasks

- $\quad$ Glass slides

Procedure

- Once cell cultures reached the $80 \%$ of cell confluence, observe under the microscope in order to determine the presence of dividing cells, this will ensure getting a good number of metaphases.

If the number of dividing cells is reduced, it is advisable to wait 24 hours before adding colchicine or Velbe. The dividing cells must be observed around (Figure 6).

- Add $20 \mu \mathrm{l}$ colcemid stock $(3,3 \mu \mathrm{g} / \mathrm{ml})$ for each $5 \mathrm{ml}$ of culture medium to give a final concentration of $0,01 \mu \mathrm{g} / \mathrm{ml}$.

- Cap the flask securely and place it on its side in the $\mathrm{CO}_{2}$ incubator at $37^{\circ} \mathrm{C}$, continue incubating for 2.5 or 3 hours.

If cell growth is slow, it is recommended to use Velbe, in this case add $200 \mu$ l of velbe solution $(0,5 \mu \mathrm{g} / \mathrm{ml})$ for each $10 \mathrm{ml}$ of culture medium, to give a final concentration of $0,01 \mu \mathrm{g} / \mathrm{ml}$. Incubate for 16 hours.

- At end of incubation, transfer the medium to a 50-ml conical centrifuge tube and add on the culture flask $10 \mathrm{ml}$ of sterile PBS; afterwards, remove carefully the PBS and transfer it to the same sterile $50-\mathrm{ml}$ tube. 


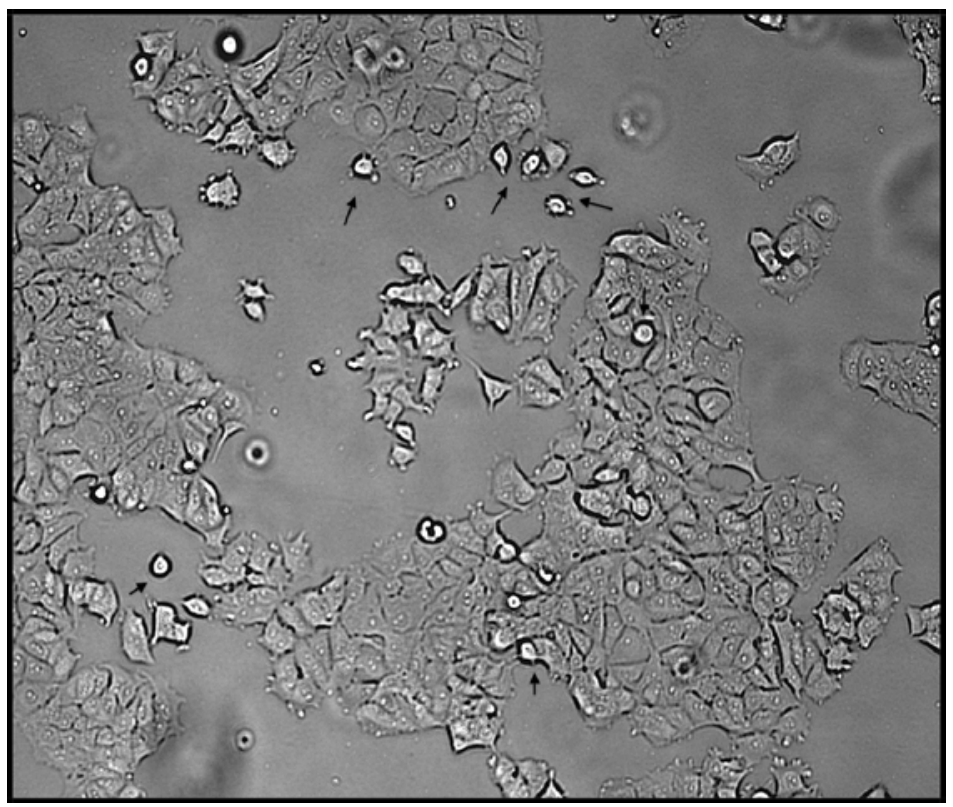

a. Cell line with few dividing cells (indicated by arrows)

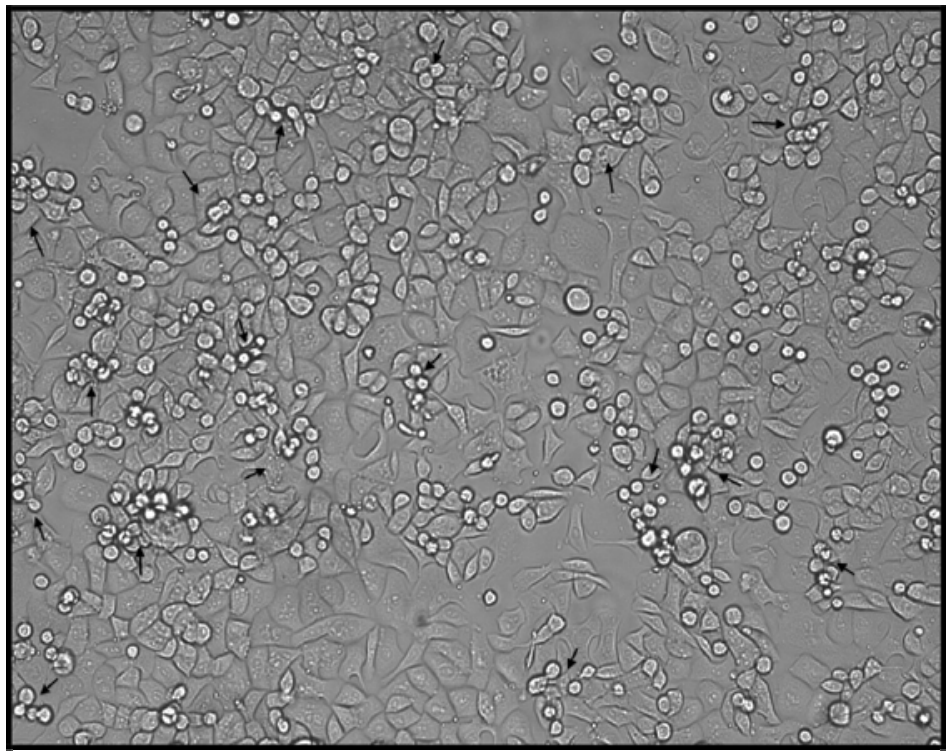

b. Cell lines with good number of dividing cells. Many groups of cells in division are observed (indicated by arrows)

Fig. 6. Cell culture displaying dividing cells. Figure a shows few dividing cells present, in this case, it is not recommended to add Colchicine or Velbe. Figure $b$ shows good number of dividing cells, enough to add the arrest agents. 
The addition of PBS to the culture flasks allows washing and removing medium traces that could interfere with the subsequent action of trypsin.

- $\quad$ Trypsinize attached cells in the flask using $1 X$ Trypsin-EDTA and let stand for 3 minutes at room temperature.

Some cell lines need to be subjected to this step at $37^{\circ} \mathrm{C}$, these temperature facilitates a fast cellular detachment, but again this will depend on the type of cell because at this temperature some cells can be damaged.

- When cells have detached, add fresh medium, collect cells and transfer them to the 50$\mathrm{ml}$ tube containing the medium and the PBS.

- Centrifuge $10 \mathrm{~min}$ at $1500 \mathrm{rpm}$ and room temperature. Discard the supernatant.

- $\quad$ Resuspend the cell pellet by gently tapping the tube base.

- Add to resuspended cells 2 or $3 \mathrm{ml}$ of prewarmed $\left(37^{\circ} \mathrm{C}\right) 0.075 \mathrm{M} \mathrm{KCl}$ (hypotonic solution) and mix gently using a plastic disposable transfer pipette. Incubate $15 \mathrm{~min}$ at $37^{\circ} \mathrm{C}$.

It is also recommended to use the hypotonic solution formed by $\mathrm{KCl} 20 \mathrm{mM}$ and Sodium Citrate 10 $m M$ for 15 min at $37^{\circ} \mathrm{C}$ when longer, twisting or overlapping chromosomes are obtained.

- $\quad$ Add $2 \mathrm{ml}$ of 3:1 cold methanol/acetic acid fixative. Cap tube and mix gently three times by inversion.

- $\quad$ Centrifuge for $10 \mathrm{~min}$ at $2500 \mathrm{rpm}$ and room temperature.

- Discard supernatant and resuspend the pellet thoroughly by flicking the bottom of the tube.

- Add 3:1 cold methanol/acetic acid fixative and mix by performing continuous movements (60 times), using a Pasteur pipette

- Centrifuge again for $10 \mathrm{~min}$ at $2500 \mathrm{rpm}$ and room temperature. Discard supernatant and resuspend pellet by flicking gently the tube bottom.

- Repeat fixation by adding $5 \mathrm{ml}$ of fixative, resuspend 50 times with pipette.

- $\quad$ Place the tube into the refrigerator for 20 minutes at $-20^{\circ} \mathrm{C}$.

This step optimizes the action of the fixative solution and allows obtaining cleaner chromosome spreads.

- Centrifuge again for $10 \mathrm{~min}$ at $2500 \mathrm{rpm}$ and room temperature. Discard supernatant and resuspend pellet by flicking gently the tube bottom.

- Repeat fixation and centrifugation once more.

- Discard fixative, add sufficient fixative in such a way that the suspension appears opaque and resuspend using a Pasteur pipette.

- $\quad$ Take a slide previously placed in ethanol, dry and clean it properly and hold roughly at a $45^{\circ}$ angle.

Slides to be used for chromosomal analysis should be carefully cleaned and degreased; keep the slides in a container with $70 \%$ ethanol and stored at $-20^{\circ} \mathrm{C}$, this allows the slides to be clean and free of grease. Before its use, wipe them with a dust-free cloth.

- Using a 1-ml plastic disposable transfer pipet, add 3 drops of the cytogenetic suspension. Allow the slide to dry. 
Is important to control or maintain proper temperature and humidity conditions $\left(27^{\circ} \mathrm{C}, 42 \%\right.$ humidity). This will allow us to obtain a proper chromosomal dispersion. If these conditions are not controlled, you will probably get closed metaphases with lapped chromosomes, which are not suitable for chromosome analysis.

- After laying the first slide, examine the following items by phase-contrast microscopy: mitotic index, chromosomal dispersion and presence of cellular debris. This will give an indication of the changes that need to be carried out in order to obtain optimal chromosome spreads.

If the chromosomal dispersion is not appropriate and you find lapped chromosomes, it is recommended to add distilled water on the slide and immediately drop the cell suspension (before the cell suspension). Afterwards, put the slide on serological bath preheated to $68^{\circ} \mathrm{C}$, so that the steam produced baths the opposite side of the slide, where the chromosome spread has been performed. This will allow the slow evaporation of the fixative solution to contribute to good chromosome dispersion. If the evaporation of the fixative solution is fast, the chromosomes will not have enough time to separate from each other, and you may obtain lapped chromosomes (Figure 7). Otherwise, If the mitotic index is low, you could try applying Velbe (if colchicine has been previously applied). The low mitotic index could indicate a low proliferative index of the cell line (Figure 8)

- Store the pellet eventually left in an Eppendorf tube, using $1 \mathrm{ml}$ of fresh fixative at $-20^{\circ} \mathrm{C}$ for further use.

- $\quad$ Finally, make banding following the protocol previously mentioned (Protocol 3.2.5)

The application of cytogenetics in cancer has acquired in the last two decades great importance not only as invaluable diagnostic tool but as a powerful research tool. As a diagnostic tool has allowed the identification of chromosomal aberrations and understanding among others, of malignant transformation in many cancers, which has provided important information about the biology of cancer. As a research tool provides

a.
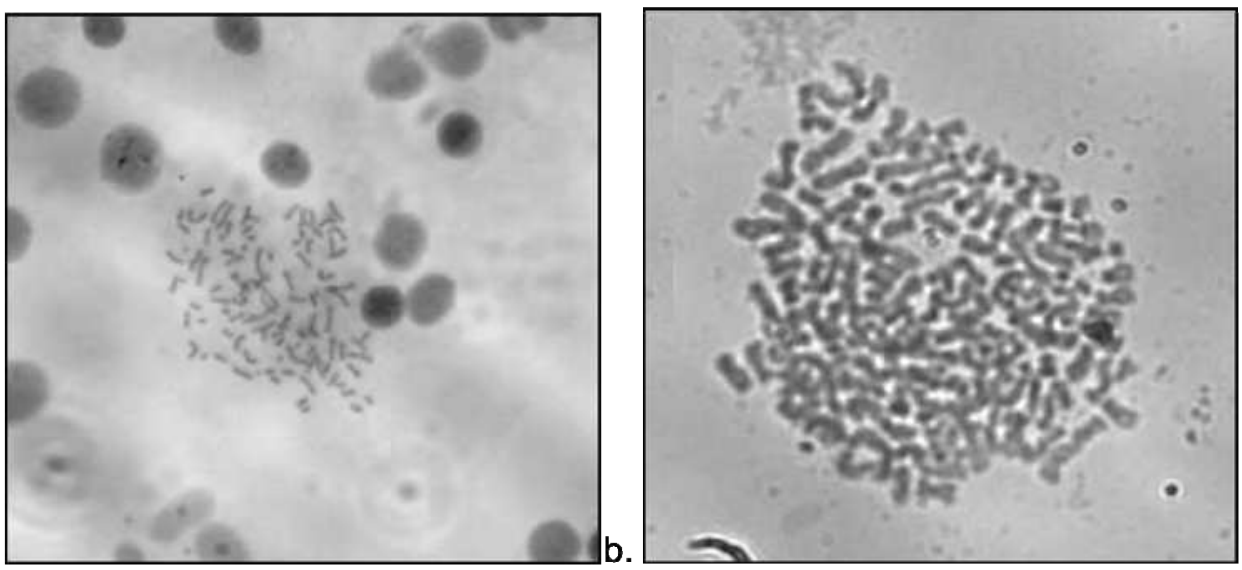

Fig. 7. Phase-contrast images of slides that are appropriate and not appropriate for cytogenetic analysis. (a) This metaphase shows good chromosome dispersion and chromosomes having a proper length for banding analysis. (b) This metaphase shows overlapping chromosomes, which are not appropriate for banding analysis. 
a)

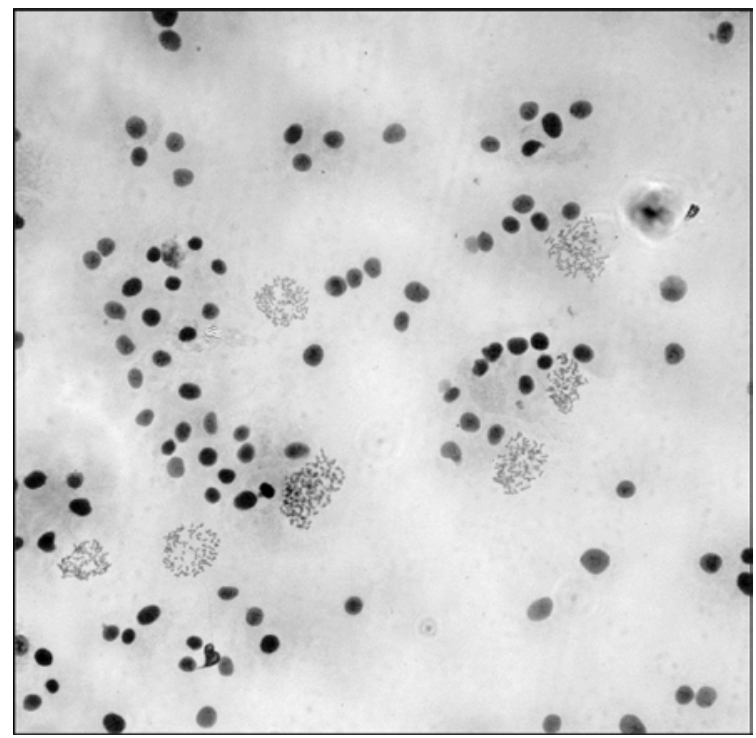

b)

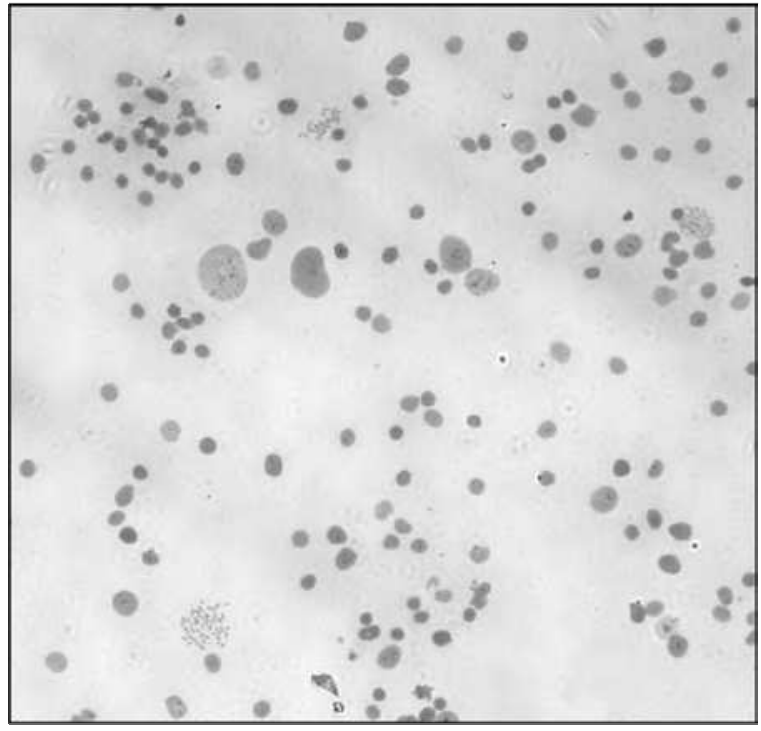

Fig. 8. Phase-contrast images of slides that are appropriate and not appropriate for cytogenetic analysis. (a) Chromosome spread showing a good number of intact metaphases, which is appropriate for analysis and indicates that the dilution of the cell suspension in fixative is good. (b) Chromosome spread displaying a low number of metaphases, the cell suspension needs to be centrifuged again and resuspended in a smaller amount of fixative, which allows the concentration of a greater number of metaphases. 
information about specific aberrations of a new type of cancer genes possibly involved in postulating the same, which can be analyzed in more detail by molecular studies, thus allowing a greater understanding of the molecular mechanisms envolved in carcinogenesis. Given the above, the knowledge and use of cytogenetic techniques allow proper application both in the diagnostic field or research directed toward improving our knowledge in various pathologies associated with chromosomal abnormalities.

\section{References}

Burdall, S. E., Hanby, A. M., Lansdown, M. R., \& Speirs, V. (2003). Breast cancer cell lines: friend or foe? Breast Cancer Res, 5(2), 89-95.

Daly, E. M., \& Taylor, R.E. (2009). Entropy and Enthalpy in the Activity of Tubulin-Based Antimitotic Agents. Current Chemical Biology, 3, 367-379.

Hevir, N., Trost, N., Debeljak, N., \& Rizner, T. L. (2011). Expression of estrogen and progesterone receptors and estrogen metabolizing enzymes in different breast cancer cell lines. Chem Biol Interact, 191(1-3), 206-216.

Keydar, I., Chen, L., Karby, S., Weiss, F. R., Delarea, J., Radu, M., et al. (1979). Establishment and characterization of a cell line of human breast carcinoma origin. Eur J Cancer, 15(5), 659-670.

Lasfargues, E. Y., Coutinho, W. G., \& Dion, A. S. (1979). A human breast tumor cell line (BT$474)$ that supports mouse mammary tumor virus replication. In Vitro, 15(9), 723729.

Lasfargues, E. Y., Coutinho, W. G., \& Redfield, E. S. (1978). Isolation of two human tumor epithelial cell lines from solid breast carcinomas. J Natl Cancer Inst, 61(4), 967-978.

Lattrich, C., Juhasz-Boess, I., Ortmann, O., \& Treeck, O. (2008). Detection of an elevated HER2 expression in MCF-7 breast cancer cells overexpressing estrogen receptor beta1. Oncol Rep, 19(3), 811-817.

MacLeod, R. A., Dirks, W. G., Matsuo, Y., Kaufmann, M., Milch, H., \& Drexler, H. G. (1999). Widespread intraspecies cross-contamination of human tumor cell lines arising at source. Int J Cancer, 83(4), 555-563.

Marcovic, O., \& Marcovic, N. (1998). Cell cross-contamination in cell cultures: the silent and neglected danger. In Vitro Cell Dev Biol, 34, 108.

Masters, J. R. (2002). HeLa cells 50 years on: the good, the bad and the ugly. Nat Rev Cancer, 2(4), 315-319.

Masters, J. R., Thomson, J. A., Daly-Burns, B., Reid, Y. A., Dirks, W. G., Packer, P., et al. (2001). Short tandem repeat profiling provides an international reference standard for human cell lines. Proc Natl Acad Sci U S A, 98(14), 8012-8017.

Osborne, C. K., Hobbs, K., \& Trent, J. M. (1987). Biological differences among MCF-7 human breast cancer cell lines from different laboratories. Breast Cancer Res Treat, 9(2), 111121.

Van Bokhoven, A., Varella-Garcia, M., Korch, C., Hessels, D., \& Miller, G. J. (2001). Widely used prostate carcinoma cell lines share common origins. Prostate, 47(1), 36-51. 


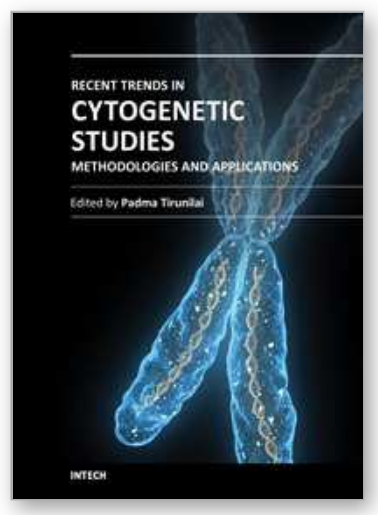

\author{
Recent Trends in Cytogenetic Studies - Methodologies and \\ Applications \\ Edited by Prof. Padma Tirunilai
}

ISBN 978-953-51-0178-9

Hard cover, 146 pages

Publisher InTech

Published online 02, March, 2012

Published in print edition March, 2012

Recent Trends in Cytogenetic Studies - Methodologies and Applications deals with recent trends in cytogenetics with minute details of methodologies that can be adopted in clinical laboratories. The chapters deal with basic methods of primary cultures, cell lines and their applications; microtechnologies and automations; array CGH for the diagnosis of fetal conditions; approaches to acute lymphoblastic and myeloblastic leukemias in patients and survivors of atomic bomb exposure; use of digital image technology and using chromosomes as tools to discover biodiversity. While concentrating on the advanced methodologies in cytogenetic studies and their applications, authors have pointed out the need to develop cytogenetic labs with modern tools to facilitate precise and effective diagnosis to benefit the patient population.

\title{
How to reference
}

In order to correctly reference this scholarly work, feel free to copy and paste the following:

Sandra Milena Rondón Lagos and Nelson Enrique Rangel Jiménez (2012). Cytogenetic Analysis of Primary Cultures and Cell Lines: Generalities, Applications and Protocols, Recent Trends in Cytogenetic Studies Methodologies and Applications, Prof. Padma Tirunilai (Ed.), ISBN: 978-953-51-0178-9, InTech, Available from: http://www.intechopen.com/books/recent-trends-in-cytogenetic-studies-methodologies-andapplications/cytogenetic-from-primary-cultures-and-cell-lines-applications-protocols-and-nomenclature

\section{INTECH}

open science | open minds

\author{
InTech Europe \\ University Campus STeP Ri \\ Slavka Krautzeka 83/A \\ 51000 Rijeka, Croatia \\ Phone: +385 (51) 770447 \\ Fax: +385 (51) 686166 \\ www.intechopen.com
}

\author{
InTech China \\ Unit 405, Office Block, Hotel Equatorial Shanghai \\ No.65, Yan An Road (West), Shanghai, 200040, China \\ 中国上海市延安西路65号上海国际贵都大饭店办公楼 405 单元 \\ Phone: +86-21-62489820 \\ Fax: +86-21-62489821
}


(C) 2012 The Author(s). Licensee IntechOpen. This is an open access article distributed under the terms of the Creative Commons Attribution 3.0 License, which permits unrestricted use, distribution, and reproduction in any medium, provided the original work is properly cited. 